RAHMAH ELFITHRI, MD PAUZI ABDULLAH, AHMAD FUAD EMBI, MAZLIN BIN MOKHTAR, MOHD

EKHWAN TORIMAN, MUHAMMAD BARZANI GASIM, SAHIBIN ABD RAHIM, MAIMON ABDULLAH, ANIZAN ISAHAK, NOOR EZLIN AHMAD BASRI, NORMAIZURA MAIZAN

\title{
DEVELOPMENT OF A COMPREHENSIVE MODEL FOR EROSION AND SEDIMENT CONTROL TOWARDS GOOD WATER GOVERNANCE: UKM CAMPUS AS A WATERSHED MODEL
}

\author{
(Date received: 16.07.2021/Date accepted: 21.09.2021)
}

${ }^{1}$ Rahmah Elfithri, ${ }^{2}$ Md Pauzi Abdullah, ${ }^{3}$ Ahmad Fuad Embi, ${ }^{1}$ Mazlin bin Mokhtar, ${ }^{4}$ Mohd Ekhwan Toriman, ${ }^{2}$ Muhammad Barzani Gasim, ${ }^{2}$ Sahibin Abd Rahim, ${ }^{2}$ Maimon Abdullah, ${ }^{2}$ Anizan Isahak, ${ }^{3}$ Noor Ezlin Ahmad Basri, ${ }^{2}$ Normaizura Maizan

\begin{abstract}
${ }^{1}$ Institute for Environment and Development (LESTARI), Universiti Kebangsaan Malaysia (UKM), 43600, Bangi, Selangor, Malaysia
${ }^{2}$ Faculty of Science and Technology (FST), Universiti Kebangsaan Malaysia (UKM), 43600, Bangi, Selangor, Malaysia

${ }^{3}$ Faculty of Engineering and Built Environment, Universiti Kebangsaan Malaysia (UKM), 43600, Bangi, Selangor, Malaysia

${ }^{4}$ Faculty of Social Science and Humanities, Universiti Kebangsaan Malaysia (UKM), 43600, Bangi, Selangor, Malaysia
\end{abstract}

Email: elfith@ukm.edu.my

\section{ABSTRACT}

This study was carried out to develop a whole ecosystem-based erosion and sediment transport control management system of UKM Campus Watershed which is a sub-basin of Langat River Basin catchment. This is done through the development of an Erosion and Sediment Control (ESC) model for the UKM campus watershed that includes localised technology, information and communication system, as well as awareness and community participation for the greening and rehabilitation of UKM Campus. The management system was developed to give a strong participatory element and to ensure that the model will be placed into a user friendly context to make data input and model operation simple for stakeholders with limited resources and training in the use of the models. The application of hydromulching (bioengineering technology) is adopted as part of the ESC study by using the local components to recover most landslides occurred in UKM Campus. It is also as an option where the post-landslide restoration works involving conventional civil designs are costly and sometimes not practical at remote sites. Therefore (due to cost constraints), the remoteness of the sites and low risk to lives and property, bioengineering was the option taken for erosion control, slope stabilization and vegetation establishment. The study successfully developed the local hydro mulching (bio engineering technology) product for erosion and sediment control of UKM campus watershed by using the local components to recover most landslides issues in UKM Bangi Campus. The study also developed the integrated information and communication system for the campus community of UKM in order to raise awareness and to increase participation of UKM Campus stakeholders in minimising the erosion and sedimentation issues. The integrated information and communication system is coordinated under the Integtrated Water Resources Management (IWRM) Research Group of UKM, which also monitor and evaluate the erosion and sediment transport within the UKM campus.

Keywords: Erosion and Sediment Control, Water Governance, Watershed Model, Hydromulching, UKM Campus

\subsection{INTRODUCTION}

Erosion is one of the common phenomenon that can be happened in any tropical region, including Malaysia. Malaysia which is located near to the equator, being hot and wet throughout the year with annual rainfall average of $2,400 \mathrm{~mm}$ per year and the average temperature of $27^{\circ} \mathrm{C}$, being exposed to rainfall and runoff, some of construction activities and uncontrolled land disturbance, high scale of deforestation, are among factors that lead to the erosion and sedimentation issues. In Malaysia, erosion or slope failure commonly related to rapid development of land. The development includes changing forest cover area to other development such as agriculture, urbanization, industrial, infrastructure and also residential that would mismanaged the slope become non environmental friendly and causing slope failure (Jaafar et. al. 2011).

There are several factors related to this slope failure i.e (i) the occurrence of heavy rain for a long period of time, (ii) changes in the nature of the earth through geomorphologic processes, (iii) the plane of rock discontinuities and (iv) the erosion of soil by the action of rain water and runoff (Komoo 1985; 1986). Generally, landslide is associated with the movement of rocks, debris and soil down a group. Moving water is the major agent of erosion where rain carries away bits of soil and slowly washes away rock fragments (Cruden 1991; 1996).

The same situation is also occurred in UKM Campus, which has facing series of issues related to erosion and sedimentation, slope failure and landslides. The effect has been in obvious water quality and quantity deterioration in a UKM Watershed due to severe siltation and sedimentation. Sediment is always the number one pollutant in waterways, where siltation and nutrients have entered and flowed into the rivers system, and UKM is no exception. There is a need to develop a whole ecosystem-based erosion and sediment transport control management system for UKM Campus Watershed.

This study focused on the soil erosion causes, effective erosion control designs and techniques for fast greening of bare 
slope faces. In addition, there is the unsuitability of conventional hard-engineering solutions (e.g. concrete revetments) in blending in with the landscape in a campus or institutional environment like the UKM. Bioengineering solutions will not only be green in appearance, but in the long term may be cheaper to maintain due to the flexibility of vegetation in following ground level movements as compared to hard concrete structures. The monitoring and evaluation system for erosion and sediment transport within the UKM Campus will also need to be done in supporting the ongoing study.

\subsection{EROSION AND SEDIMENT CONTROL}

Erosion defined as the detachment, entrainment, and transport of soil particles from ongoing land development and construction areas by the rainfall and runoff activities (DID, 2011). Erosion occurs in form of mass movement of soils and debris down a slope, and starting with raindrop splash. At the onset of runoff sheet, water collects into small rivulets, which may erode very small channels called rills (Dilley et. al. 2005). Soil particles can be transported over a short distance (such as the splash from a raindrop impact), or a longer distance (to the bottom of the slope, or into a water conveyance) before being deposited. The transportation and deposition process is called sedimentation.

Erosion and sedimentation are natural processes. These processes occur daily, on all land, as the result of wind, and water. However, human activities can make it happen more quickly than under natural conditions. Destruction of soil is caused by abiotic factors, the activity of which is attributable to mechanical action, and is called "mechanical erosion." Erosion also includes chemical action, which is connected with the mechanical action of water, and is referred to as "chemical erosion" or "corrosion" (Zachar 1982).

The natural processes can be divided into geological erosion and also accelerated erosion. Geological soil erosion tends to bring the earth's surface to a uniform level. The first phase of this process is weathering which is essentially physico-chemical in nature. This leads to simplification of substances through disintegration and is aided by certain biological influences causing further disintegration. The process leads to the development of complex soil bodies with definite physical, chemical and biological properties. Therefore, as a part of geological process, erosion takes place through various weathering processes. While accelerated Erosion under cultivation, the land experiences a lot of pressure from outside and consequently the balance between vegetation cover and climate is disturbed. Thus, removal of surface soil by natural agencies takes place at a faster rate than it can be built up by soil forming process. Erosion occurring under these conditions is referred to as accelerated erosion. Its rate and magnitude are higher than those in normal geological erosion (Montgomery, 2007).

Soil erosion is a common geomorphological process in the tropic area and managing it is a constant challenge (Jaafar et. al. 2011). There are many impacts of soil erosion towards environment especially on soil quality, air quality and also water quality. Organic matter is a small fraction ( $2 \%$ to $4 \%$ ) of soil mainly present on the soil surface. Organic matter contributes to productivity through its effect on the physical, chemical, and biological properties of the soil. Erosion gradually depletes organic matter and decreases soil productivity. When organic matter is lost, soils tend to lose their physical structure. The degradation of soil structure makes the soil hard, compact and cloddy. The soil aeration, water-holding capacity and permeability are also decreased. Decreased aeration means less oxygen available for plant roots to grow. Decreased water availability also means less water available for healthy plant growth. When soil permeability decreases, less water will soak into the soil and more will run-off. Beneficial organisms that suppress disease and break down organic residues will not function well due to reduced oxygen and water in soil. This in turn will reduce nutrient storage and supply abilities of the soil.

While air quality have a major impact on human and animal health when the soil particles blown by the wind into the air. Particles suspended in air by wind are easily inhaled and accumulate in lung tissues causing major respiratory problems. Concentrated levels of windblown particles can also reduce visibility and increase the risk of automobile accidents. Impacts of erosion on water quality sediment deposition in lakes and rivers will increase water turbidity making it difficult for light to penetrate the water. This causes problems for aquatic plants that need sunlight for photosynthesis. Sediments are also rich in nutrients such as phosphorus and nitrogen. These nutrients promote the excessive growth of algae. This process is called eutrophication. Areas of excessive algae growth, called algae blooms, deplete oxygen in the water resulting in the death of aquatic animals from lack of oxygen (Chislock et al, 2013).

Sedimentation defined as the build-up (aggradation) of sediment on the land surface or the bed of receiving waters. Sedimentation leads to the rising of bed levels contributing to increased floods levels and escalates the destruction of aquatic habitats and fisheries. It is a dynamic process and is dependent upon the geomorphic and hydraulic characteristics of the drainage system and the nature of the receiving water body (DID, 2011). The deposited sediment tends to remain in place sometimes for short periods of time, where subsequent rainstorms flush the sediment downstream and sometimes for very long times, the later being the case in estuaries and lakes. Sediment tends to be transported in pulses depending on the flow characteristics of the drainage systems. There are primarily eight basic principles of Erosion and Sediment Control (ESC) described in MSMA guideline by DID (2010) i.e. (1) Minimizing Soil Erosion; (2) Preserving Top Soil \& Other Assets; (3) Access Route \& Site Management; (4) Runoff Control \& Management; (5) Earthwork \& Erosion Control; (6) Sediment Prevention Control; (7) Slope Stabilization; and (8) Site Maintenance.

Erosion control is the process of reducing erosion by wind and water. Sometimes, engineers simply install structures to physically prevent soil from being transported. Gabions are huge wire frames that hold boulders in place, for instance. But this mitigation would exceed ten to twenty years depending on the gabion structure. Erosion control can also be done by physically changing the landscape. The plant could help to anchor the soil to the area, preventing erosion. Trees and plants hold soil in place. When people cut down the forests or plow up grasses for agriculture or development, the soil washes away and blows more easily. Water also rushes over exposed soil rather than soaking into it, and that will cause flood.

\subsection{STUDY AREA AND RESEARCH METHODOLOGY}

\subsection{Study Area}

The study on the development of a comprehensive model for erosion and sediment control is done at UKM Campus which is 


\section{RAHMAH ELFITHRI, MD PAUZI ABDULLAH, AHMAD FUAD EMBI, MAZLIN BIN MOKHTAR, MOHD EKHWAN TORIMAN, MUHAMMAD BARZANI GASIM, SAHIBIN ABD RAHIM, MAIMON ABDULLAH, ANIZAN ISAHAK, NOOR EZLIN AHMAD BASRI, NORMAIZURA MAIZAN}

seen as a watershed model for a bigger catchment area of Langat River Basin of Malaysia. UKM Campus Watershed is a subbasin of Langat River Basin, which is currently identified as one of the UNESCO-IHP Hydrology for the Environment, Life and Policy (HELP) Basins out of 91 catchments from 67 countries in the world since 2004. HELP (Hydrology for Environment, Life and Policy) is a cross cutting and transdisciplinary initiative of the UNESCO led by the International Hydrological Programme (IHP) with objectives to deliver social, economic and environmental benefits to stakeholders through sustainable and appropriate use of water by directing hydrological science towards improved integrated catchment management basins and also implementation of research in collaboration between scientists, managers and stakeholders (UNESCO, 2004). In order to makesure the Langat River Basin to be promoted to an Operational or Demonstration HELP Basin, it is important to conduct a more systematic and holistic study, using multisectoral and multidisciplinary approach, and therefore the study conducted under this project will also be focused on the transdisciplinary initiative and comprehensive approach for managing UKM Campus watershed which taking into account the scientific, bio-engineering and social components. This is among the reason why we need to manage the UKM Campus Watershed properly and take necessary actions to mitigate the ecosystem degradation related issues (especially those which related to erosion and sediment control) in UKM to be occurred, beside UKM Campus itself is located at the centre part of Langat River Basin. By seeing \& treating a UKM campus as a watershed model, only then we can better manage and act, as well as able to measure the catchments progress (UKM Campus Watershed) towards good water governance which implementing the HELP philosophy and long-term sustainable development within the river basin concept harmonisingly.

UKM Campus is located in humid tropical zone with nearly constant temperature throughout the year and high annual rainfall. These elements expose to geomorphological agent actions that capable to higher the potential of landslide at slope area. The annual average temperature is $23.3^{\circ} \mathrm{C}$ while total amount of rainfall is $175.9 \mathrm{~mm}$ per year recorded in UKM Station Meteorological Department in 2012. Bangi area, where UKM Campus is located, is divided by three geology structures which are alluvium, granite and metasediment (Komoo 1984). In UKM Bangi Campus context, metasediment rock is dominant that consist of meta-argillite type which is fine-grained and meta-arenit which is coarse-grained (Muda \& Komoo 1984). The combination of both rocks effected erodibility level that lack of cohesive and potentially disintegrate easily towards soil surface and sub-soil surface layer. Soil type in UKM Bangi Campus are from Munchong-Seremban series, which categorized in tropeptic subgroup. This soil is fragile, easily broken and easily absorbed water and also contain of $42.5 \%$ clay. The combination of all these features gives early indicator to slope failure around UKM Bangi Campus.

There are several series of landslides events in UKM Bangi Campus identified since May 2012 as shown in Figure 1 and 2. Landslides occurred in the UKM Bangi Campus driven by three main factors, i.e (i) slope vulnerability of materials engineering aspects associated with the low level of soil erodibility, (ii) accumulation of excessive ground water occurred for a long time, and (iii) very less preventative measures against the slope and surface slope to encourage further erosion events (Komoo 1987).

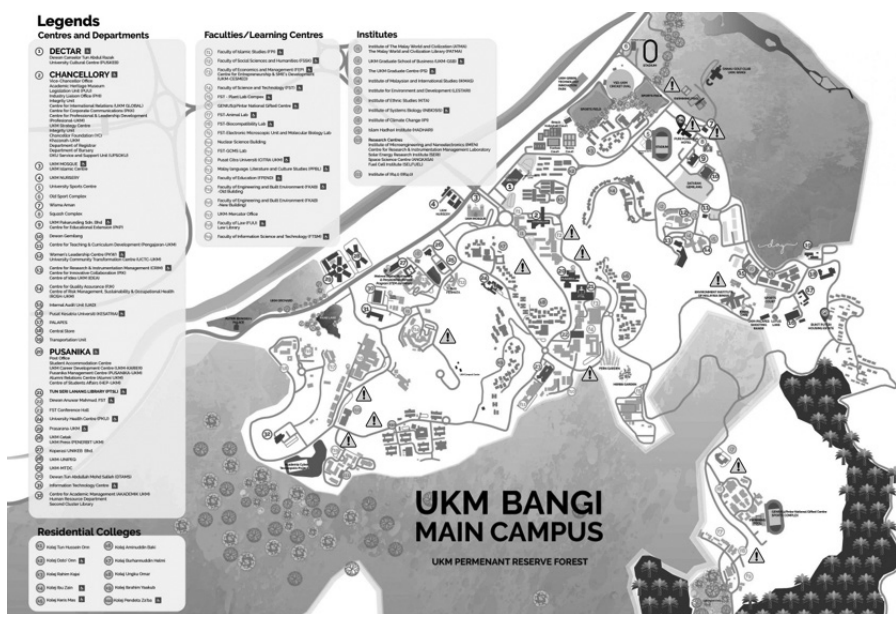

Figure 1: Landslide Locations in UKM Bangi Campus (shown by using warning signages)
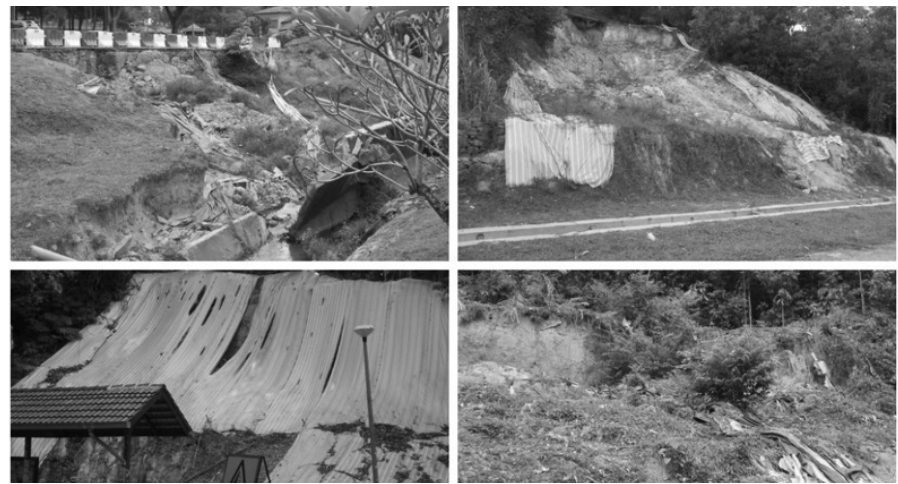

Figure 2: Landslides occurred in UKM Bangi Campus

Slope failures in UKM are also influenced by soil properties. Some of these slopes were through appropriate mitigation approach and others are become worst without any big action plan taken (Jaafar et. al. 2011). There is just a preventive action such as by putting the plastic canvas linen to cover it, but it only for a short period of time because the linen is easily torn. The composition of the soil texture was dominated by sand and silts which are significantly influenced the level of the erosion. This has shown that several problematic slopes that have not yet been mitigated should be rehabilitated immediately to avoid any possibility of large scale landslide occurrence in the future (Huat et. al. 2008).

UKM Campus is developed very fast recently, with many new buildings development in the campus, and also renovation of number of old buildings. These involved huge of land clearing area, some land use changed area, as well as lots of engineering and construction works during the developments. The process is also taking some times. Whenever heavy rain comes, soil erosion and sediment transport will be occurred by surface runoff and deposited downstream to the detention ponds, i.e into Alur Ilmu (Small Canal within UKM Campus) and also into University Lake (UKM Lake near Faculty of Engineering and Built Environment of UKM). Sediment accumulates in detention ponds and impounded water bodies over time that will affect their chemical, physical and also biological processes (Heal et. al. 2006). Detention ponds provide three basic functions that are as flood control, water quality enhancement and also ecological and aesthetic value. Continued accumulation and deposition of sediments may lead to the deterioration of water quality and the migration of pollutants through sediments (Shamsuddin et al, 2012). When this is happened, the excessive suspended sediment settled in the detention pond and may affect the detention pond function (Figure $3 \& 4$ ). 

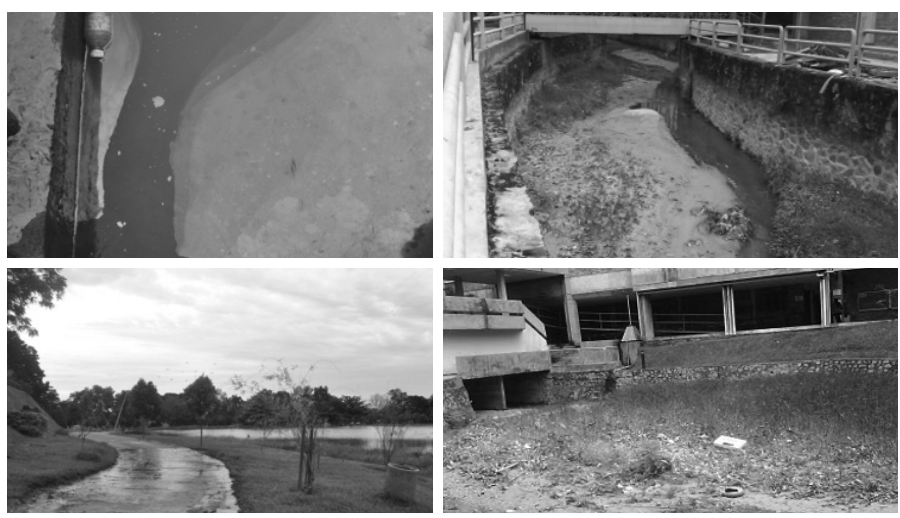

Figure 3: Erosion and sediment issues at Alur Ilmu UKM
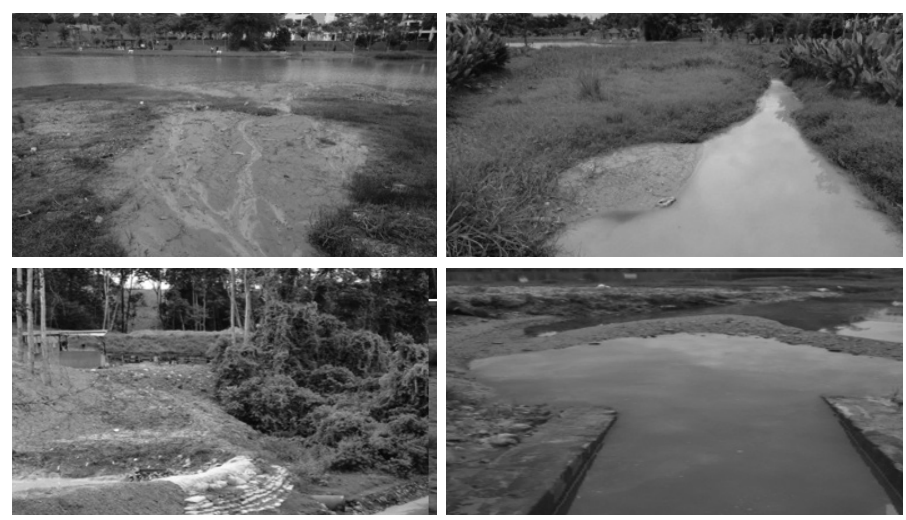

Figure 4: Erosion and sediment issues at University Lake of UKM

The same condition has also affected the UKM Campus watershed and its University Lake, which acted as a detention pond for the University. However, the lake is currently not functioning anymore due to the sediment that being transported from the landslides and erosion into the lake through drainage system which casued by rapid development activities in the UKM Campus. The sediment eroded from erosions, suspended solid and any materials in the detention pond should be removed to ensure the detention pond work effectively. Lots of works and initiatives need to be done to makesure the sediment that being transported from those erosions can be minimized in order to makesure the detention pond functioning as before.

This is why and where Erosion and Sediment Control (ESC) need to be done urgently in UKM through application of bio-engineering technology as part of the ESC study. It is also as an option where the post-landslide restoration works involving conventional civil designs are costly and sometimes not practical at remote sites. Therefore (due to cost constraints), the remoteness of the sites and low risk to lives and property, bioengineering was the option taken for erosion control, slope stabilization and vegetation establishment.

\subsection{Research Methodology}

The initiative to counter the impact of Erosion and Sediment in UKM is done through the development of an Erosion and Sediment Control (ESC) Model for UKM campus watershed that includes localised technology, information and communication system, as well as awareness and community participation for the greening and rehabilitation of UKM Campus (Figure 5 \& 6) to achieve these following objectives:

a) To develop a local hydro mulching (bio engineering) technology for erosion and sediment control of the UKM campus watershed. b) To develop an integrated information and communication system for the campus community of UKM in order to raise awareness and to 'buy-in' the involvement of all stakeholders

c) To monitor and evaluate the erosion and sediment transport within the UKM Campus.

The management system is also being developed to give a strong participatory element and to ensure that the model will be placed into a user friendly context to make data input and model operation simple for stakeholders with limited resources and training in the use of the models.

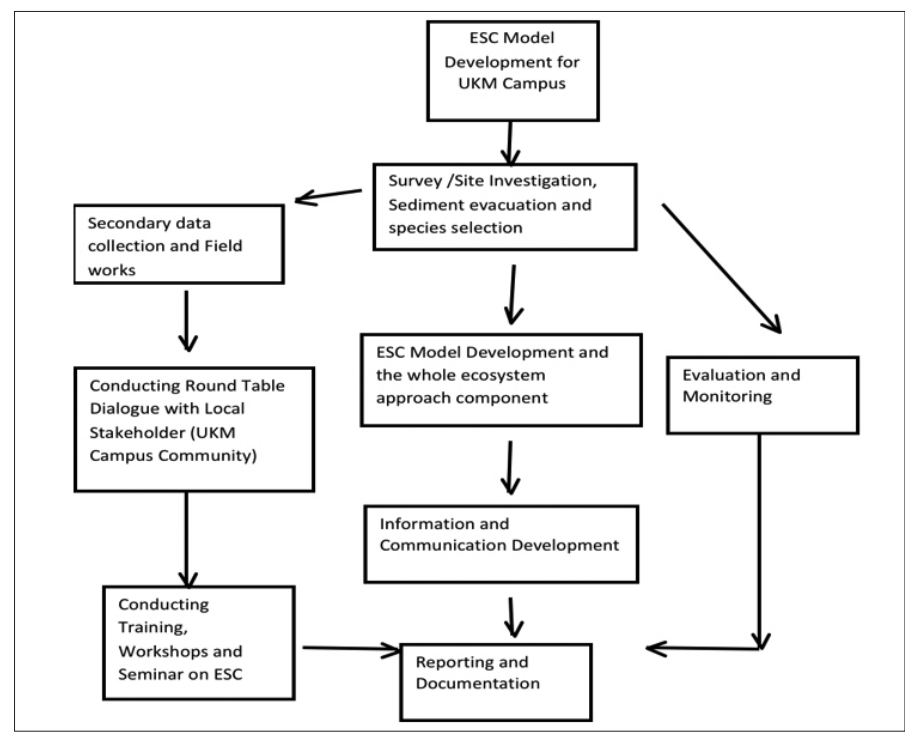

Figure 5: Research Framework of Development of ESC Model for UKM Campus

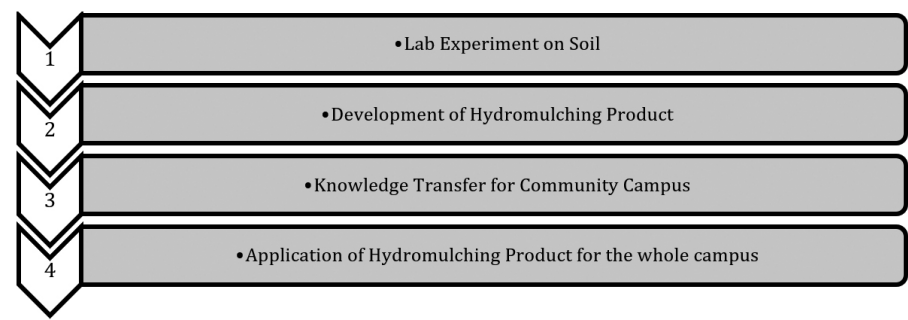

Figure 6: Sequences of erosion and sediment control activities within UKM Bangi Campus

\subsection{RESULTS AND DISCUSSION}

\subsection{Development of Local Hydromulching Product}

The application of hydromulching (bioengineering technology) is adopted as part of the ESC study by using the local components to recover most landslides occurred in UKM Campus. It is also as an option where the post-landslide restoration works involving conventional civil designs are costly and sometimes not practical at remote sites. Therefore (due to cost constraints), the remoteness of the sites and low risk to lives and property, bioengineering was the option taken for erosion control, slope stabilization and vegetation establishment.

It is found that there are plenty of bare soils exposed to erosion and excessive sediment transport in UKM, there is no Mulching method and approach currently practiced in UKM. The typical grass cutting in UKM are also too close to the ground, mostly poor and lack of buffer zones, and very much exposed to erosion and sedimentation issues without any preventive and 


\section{RAHMAH ELFITHRI, MD PAUZI ABDULLAH, AHMAD FUAD EMBI, MAZLIN BIN MOKHTAR, MOHD EKHWAN TORIMAN, MUHAMMAD BARZANI GASIM, SAHIBIN ABD RAHIM, MAIMON ABDULLAH, ANIZAN ISAHAK, NOOR EZLIN AHMAD BASRI, NORMAIZURA MAIZAN}

mitigation action being undertaken. Figure 7 shown plenty of bare soils exposed to erosion and sedimentation in UKM.
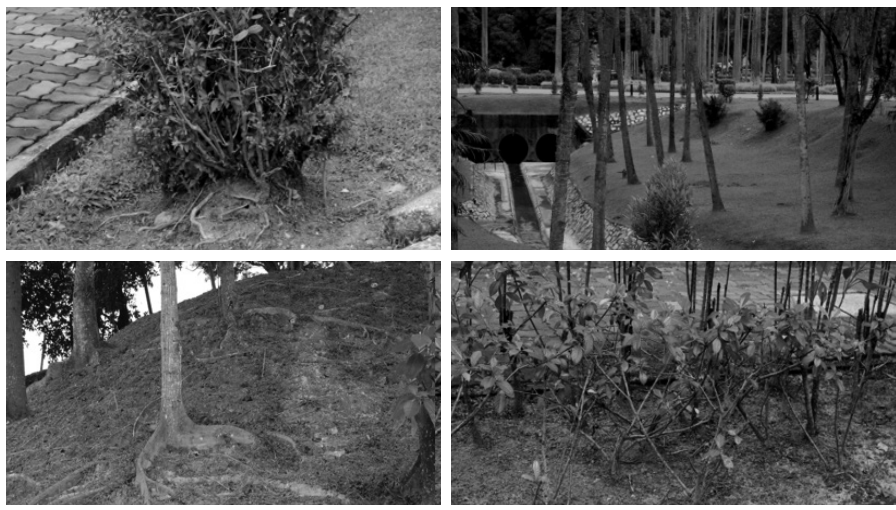

Figure 7: Some pictures showing plenty of bare soils exposed to erosion and sedimentation in UKM Campus

Mulching is one of the methods used for effective management of erosion and landslides. Mulching is a method of closing the exposed soil with no ground cover plants using organic materials, sawdust, rice husk and also coconut husk as a fibres. Apart from reducing the impact of the effects of rain, mulch also acts as a holder of the grass roots, retain soil moisture, increasing the permeability of the soil and prevent fertilizer from passes out due to rain (Moradi et al 2012).

Hydro mulching is one alternative to traditional planting or sowing seeds. Hydro mulch that will be produced is a process that uses the cultivation of seeds and hydro fluid as the main ingredient. While other materials such as fibre, latex and organic fertilizer as by-products. Mixed materials will be embedded in a tank that is connected to the machine which then will be applied to the exposed slopes.

In UKM, the local hydromulching product is being developed by using the local materials from gardening and trees cutting waste, which has processed in form of green compos product. It will then be generated as hydromulching product that is processed by using a Hydromulching Machine owned by UKM since 2013 (Figure 8). The hydromulching product is produced as an approach to prevent the slope in the future with plant growth.

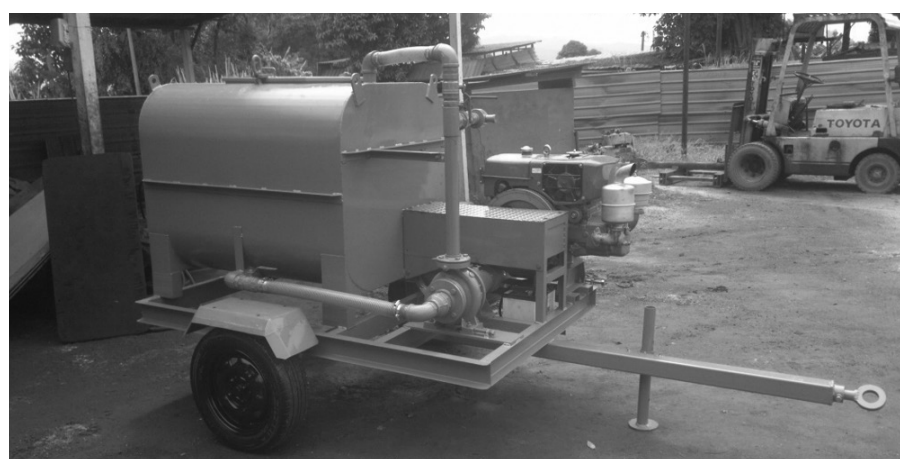

Figure 8: Hydromulching Machine in UKM

Once sprayed, the mixture of wet fiber will create a strong bond between the land will protect seeds from other factors such as sunlight, wind and erosion. When the seeds begin to germinate, the fibre will begin to decompose above compounds will be supplied nutrients to the soil. Fiber used in the method of hydro mulch can increase soil moisture levels and thus the seeds will speed up germination rate (Parsakhoo et al 2018). Figure 9 shown Hydromulching product sprayed on to soil to cover open slope area that is also produced in UKM under this study.

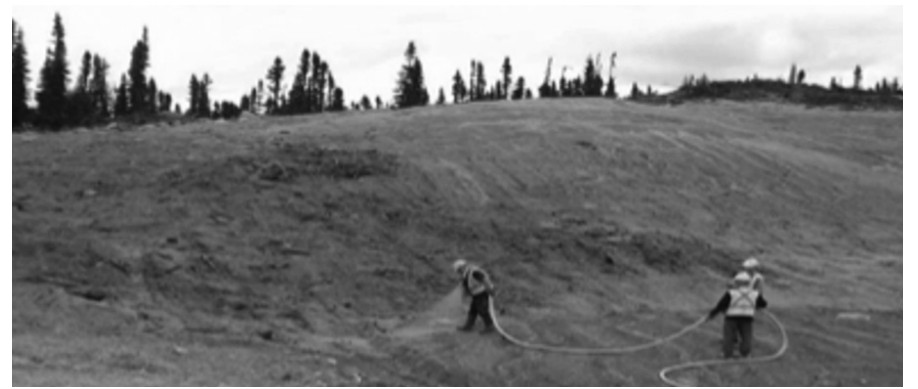

Figure 9: Hydromulching product sprayed on to soil to cover open slope area to be produced in UKM

After hydro mulching material is applied through a hose to the surface of the slope, it will be green in colour that is similar to the germination of seeds within a period of four to five weeks depending on weather conditions. The green color will fade in a few days before the seeds will begin to germinate. Hydro mulching materials to be produced is based on a formula of practice by a company in Santa Barbara, California with $60 \%$ of fibre, $30 \%$ of organic fertilizer, $5 \%$ of the seeds and the rest is a mixture of latex, water and organic dye green colour. Plants provide protective cover on the land and prevent soil erosion by slow down water as it flows over the land (runoff) and this allows much of the rain to soak into the ground; plant roots hold the soil in position and prevent it from being washed away; plants break the impact of a raindrop before it hits the soil, thus reducing its ability to erode; plants in wetlands and on the banks of rivers are of particular importance as they slow down the flow of the water and their roots bind the soil, thus preventing erosion (Ramphele \& McDowell 1991).

The loss of protective vegetation through deforestation, over-grazing, ploughing, and fire makes soil vulnerable to being swept away by wind and water. In addition, over-cultivation and compaction cause the soil to lose its structure and cohesion and it becomes more easily eroded. Erosion will remove the top-soil first. Once this nutrient-rich layer of soil is gone, few plants will grow in the soil again. Without soil and plants the land becomes desert-like and unable to support life - this process is called desertification. It is very difficult and often impossible to restore desertified land.

\subsection{Development of Integrated Information and Communication System in UKM}

An integrated information and communication system is developed in UKM for the campus community in order to raise awareness and community participation of all stakeholders for the greening and rehabilitation of UKM Campus. Since the project is focusing on UKM Campus, therefore campus community is the main target group which involving all students, academics, staffs, management, contractors, suppliers, and other related parties in UKM. The knowledge regarding erosion and sediment control should be transferred in order to make the campus community aware with their surroundings. Sometimes people are not really aware about their environment and surroundings because they thought it is not part of their job or responsibility, but more to campus management. Initiative to make them aware and responsible is necessary and urgently needed. This is also being undertaken through various awareness and public participation or community engagement programmes such as campaign, dialogue, workshop, carnival and competition.

Under this study, the round table dialogue (RTD) with the campus community on water resources management in UKM Campus was held in 2012 as an initiative to bring together the 


\section{DEVELOPMENT OF A COMPREHENSIVE MODEL FOR EROSION AND SEDIMENT CONTROL TOWARDS GOOD WATER GOVERNANCE: UKM CAMPUS AS A WATERSHED MODEL}

campus top management, lecturers, researchers, staffs and students from various faculties, research institutes, and residential colleges in UKM, as well as private entities that have direct involvement with UKM in the development and daily business activities such as contractors, developers, suppliers and cafeteria owners in UKM. The main objectives of this RTD is to identify issues and challenges on water resources management and development within UKM Campus, to increase awareness and campus community participation in water resources management, to develop a communication system and knowledge transfer within UKM Campus and also create better problem solving initiative. During RTD, many issues related to water resources management have raised and discussed, especially on water resources pollution that caused by erosion and sediment around UKM Bangi Campus.

A special workshop on development of ESC guideline has also conducted in 2013 as continuation of above RTD on Water Resources Management within campus community. This is also as an initiative to develop a comprehensive manual and guideline to overcome erosion and sediment issues in UKM Campus (as a main suggested output from previous RTD). The objectives of the workshop are to identify issues related to erosion and sediment control in UKM and to propose comprehensive guideline for erosion and sediment control to be applied in UKM Campus. During the workshop, a draft of Guideline on Erosion and Sediment Control in UKM Campus has produced and currently in the process of final editing to be published. The guideline is planned and designed to be simple and easily understood by all and to be practically practiced in daily life or businesses.

Other than that, campaign is one of the best way to increase community participation. Knowledge could transfer more easily in order to change their behaviour and perspective with the awareness towards their environment. Campaign and special event focusing on ESC and especially on Hydromulching product is still in planning to makesure campus commmunity will be aware on ESC related issues and on how to prevent it to be happened again in the future and mitigate the impacts on human and environment. It will also to disseminate information and extend knowledge about our product i.e hydromulching to protect the slope from erosion and sediment.

\subsection{CONCLUSIONS AND RECOMMENDATIONS}

This study successfully developed the local hydro mulching (bio engineering technology) product for erosion and sediment control of UKM campus watershed by using the local components to recover most landslides issues in UKM Bangi Campus. By applying this hydro mulching product, it will protect the soil erosion and control the production of sediment being transported from the landslide. Hence, the detention pond in UKM act as a good watershed model by minimized the amount of sediment deposited.

This study also developed the integrated information and communication system for the campus community of UKM in order to raise awareness and to increase participation of UKM Campus stakeholders in minimising the erosion and sedimentation issues. The integrated information and communication system is coordinated under the Integtrated Water Resources Management (IWRM) Research Group of UKM, which also monitor and evaluate the erosion and sediment transport within the UKM campus.

Some recommendations under this study included following basic actions to be undertaken especially for construction of new buildings in UKM, for rehabilitation of UKM ponds (Alur Ilmu and University Lake) and for maintenance activities in UKM. These will enable erosion and sediment control (ESC) to be effected in future. The proposed actions address present shortcomings in the overall approach and overcome perceived limitations in budgeted allocation for buildings and ponds, which has always been quoted as the reason for ESC measures not being implemented in the past few years. The proposed guides for new building construction in UKM are described as follow:

1. Fit the building to the site (not the site to the building)

This frequently neglected measure alone can be the single biggest contributor to solving the bulk of erosion and sediment problems during earthworks stage. What this means is that the architect should be clearly instructed right at the beginning to fit the building to the terrain - it being mostly hilly in UKM, and minimize "cut and fill" i.e. earthworks. Most of past problems in ESC during building construction stem from the design requiring a flat platform for the building (i.e. fitting the site to the building) which had to be carved out from the hill at the site. A building which utilizes cascading platforms following the contours of the site will minimize earthworks.

2. Require an ESCP for the site (the ESCP must be fully implemented and monitored by competent Inspectors)

An ESCP (erosion and sediment control plan) is mandatory under the new Regulations to EQA 2012 which is expected to come into force soon. At the minimum, in case of a small building, this means simple plans which show how the erosion and sediment from the earthworks during construction stage, will be controlled. All other buildings will have to have proper ESCPs prepared by a "competent person” i.e. a certified CPESC (certified professional in erosion and sediment control).

3. Incorporate the latest BQ from PWD (All BQs for all future Building Contracts must contain provisions for ESCP and BMPs to be used in ESC)

The latest "technical instruction" from the Public Works Department (PWD) includes in the Bill of Quantities (BQ) for the contract, items for ESC which need to be costed for by the contractor. As such therefore, the contractor has every reason to implement the ESCP, knowing that they will be fully paid for every BMP (best management practice) implemented. This is in contrast to the present situation where the contractor tries every trick to avoid implementing them as they are extra costs to the contractor.

4. Promote awareness at all levels (contractors, consultants, clients) There is a need to train all supervisory personnel from Department of Development Management of UKM in ESC, preferably all supervising engineers from Department of Development Management of UKM should be certified as CPESC. There is also a need to require maintenance and landscape contractors to attend an ESC course.

During this study, proposed actions for the University Lake rehabilitation and restoration are also identified which included the rehabilitation of UKM ponds with ESCP (adding flocculants, pumping/excavate-out sediment, put in BMPs to control erosion \& sediment) and restoration of Pond Ecology (water's edge vegetation, wetlands).

Last but not least, the proposed actions for maintenance activities in UKM are identified as follow:

1. Reform Maintenance Practices (Cutting to 2 in. (50 mm) only)

2. Change methodology for Grass Planting in UKM and Malaysia at whole 


\section{RAHMAH ELFITHRI, MD PAUZI ABDULLAH, AHMAD FUAD EMBI, MAZLIN BIN MOKHTAR, MOHD EKHWAN TORIMAN, MUHAMMAD BARZANI GASIM, SAHIBIN ABD RAHIM, MAIMON ABDULLAH, ANIZAN ISAHAK, NOOR EZLIN AHMAD BASRI, NORMAIZURA MAIZAN}

3. Develop a cheap, local version of BFM - can be easily sprayed on to eroding slopes to promote vegetative cover (Introduce Mulching for flower beds \& Bare soil)

Once implemented, the agenda for UKM sustainable campus and UKM campus as a comprehensive watershed model for erosion and sediment control towards good water governance will be achieved, with the participation and involvement of all campus community at all levels.

\section{ACKNOWLEDGEMENTS}

The author would like to express appreciation to UKM, which allocated the grant UKM-AP-2012-006 (Arus Perdana Project) to conduct research on the Development of a Comprehensive Model for Erosion and Sediment Control Towards Good Water Governance. Appreciation is also extended to UNESCO-IHP HELP which has supported and cooperated in the Langat River Basin Development. The author thanks all members of the Sustainable Ecosystem Management Research Group and IWRM Research Group who contributed their knowledge and expertise in R\&D.

\section{REFERENCES}

[1] Bujang B. K. Huat, Faisal Hj. Ali, David H. Baker, Harwant Singh \& Husaini Omar. 2008. Landslide in Malaysia: Occurrences, Assessment, Analyses and Remediation. Universiti Putra Malaysia, Serdang.

[2] Chislock, M. F., Doster , E., Zitomer, R. A., \& Wilson, A. E. 2013. Eutrophication: Causes, Consequences, and Controls in Aquatic Ecosystems. Nature Education Knowledge 4(4):10

[3] Cruden D. M. 1991. A simple definition of a landslide. Bulletin of International Association of Engineering Geology 43, 27-29.

[4] Cruden D. M. \& Varness D. J. 1996. Landslide types and process. In "Landslides - Investigation and Mitigation", Transportation Research Board special Report n. 247, National Academy Press, Washington DC, 36-75.

[5] DID. 2010. Guideline For Erosion And Sediment Control In Malaysia. Department of Irrigation and Drainage (DID), Kuala Lumpur, Malaysia.

[6] DID. 2011. Urban Stormwater Management Manual for Malaysia - Manual Saliran Mesra Alam (MSMA). Department of Irrigation and Drainage (DID). Kuala Lumpur, Malaysia.

[7] Dilley, M., Chen, R.S., Deichmann, U., Lerner-Lam, A. L., Arnold.
M., Agwe, J., Buys, P., Kjekstad, O., Lyon, B. and Yetman, G. 2005. Natural Disaster Hotspots: A Global Risk Analysis. Disaster Risk Management Series No 5. The World Bank.

[8] Heal, K.V., Hepburn D.A. and Lunn, R.J. 2006. Water Science and technology. Sediment Manage. Sustainable Urban Drainage Syst. Ponds 53. 219-227.

[9] Ibrahim Komoo. 1984. Aspek Geologi Kejuruteraan Bahab Bumi di Kawasan Bangi, Selangor. Ilmu Alam 12 \& 13, 41-54.

[10] Ibrahim Komoo. 1985/1986. Pengelasan Kegagalan Cerun di Malaysia. Ilmu Alam 14 \& 15. 47-58.

[11] Ibrahim Komoo. 1987. Survei Kegagalan Cerun di Kawasan Selangor. Sains Malaysiana 16(1), 1-14.

[12] Mohamad Rasik Muda \& Ibrahim Komoo. 1984. Peta Kestabilan Cerun Kawasan Bangi, Selangor. Sains Malaysiana 13(1), 9-20.

[13] Mokhtar Jaafar, Abdul Halim Yusof \& Asiah Yahaya. 2011. Analisis Tahap Kebolehruntuhan Tanah dengan Menggunakan Skala ROM: Kajian di Kampus Universiti Kebangsaan Malaysia, Bangi. Malaysia Journal of Society and Space 7(3), 45-55

[14] Montgomery, D. R. 2007. Soil erosion and agricultural sustainability. Proceedings of the National Academy of Sciences of the United States of America (PNAS) August 14, 2007. Standford University, California.

[15] Moradi, A., Christopher, T., Kahjoo, G., Hanif, A., \& Ishak, C. 2012. Evaluation of Four Soil Conservation Practices in a NonTerraced Oil Palm Plantation. Agronomy Journal.104(6):1727

[16] Parsakhoo A., Jajouzadeh M., Rezaee Motlagh A. (2018): Effect of hydroseeding on grass yield and water use efficiency on forest road artificial soil slopes. J. For. Sci., 64: 157-163.

[17] Ramphele, $\mathrm{M}$ and McDowell, C. 1991. Restoring the Land: Environment and Change in Post-Apartheid South Africa. Panos Publication. London.

[18] Supiah Shamsuddin, Irma Norazurah Mohamad \& Azmi Ab Rahman. 2012. Detention Pond Sediment Accumulation Prediction Using Monte Carlo Simulation. American Journal of Environmental Sciences 8(1). 25-34.

[19] UNESCO. 2004. Hydrology for the Environment, Life and Policy (HELP) - United Nations Educational, Scientific and Cultural Organization (UNESCO). (http://www.unesco.org/water/ihp/ help)

[20] Zachar, D. 1982. Soil Erosion. Developments in Soil Science. Volume 10. Elsevier Science. 547 Pp.

\section{PROFILES}

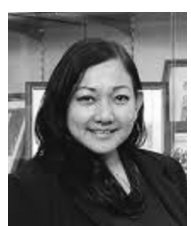

RAHMAH ELFITHRI is a Visiting Professor at the National University of Malaysia (UKM). She received her BSc (Hons.) Environmental Science in 1999, Master in Environmental Management in 2000 and PhD in Environment and Development (IWRM) in 2006 from UKM, Malaysia. She started her academic and research career almost 15 years ago in 2007 as a Lecturer and Research Fellow at the Institute for Environment and Development (LESTARI), UKM. She has been coordinating the Integrated Water Resources Management (IWRM) and Sustainable Ecosystem Management Research Groups in UKM since 2008. She has conducted various research, education and capacity building programmes in areas of water, environment and sustainable development in collaboration with some Local, National and International partners/institutions, and has published more than 300 publications in the forms of journals, books/ chapters in books, proceedings, etc. Email address: elfith@ukm.edu.my / elfith@gmail.com

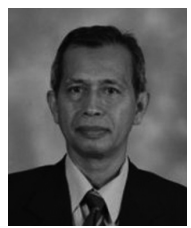

MD PAUZI ABDULLAH was a Professor of Analytical Chemistry and Environmental Chemistry at the School of Chemical Sciences and Food Technology, Faculty of Science and Technology, National University of Malaysia (UKM). He holds PhD (Analytical Chemistry), University of Wales, U.K. (1981); MSc (Analytical Chemistry), University of Salford, U.K. (1977); and BSc (Chemistry), from UKM (1974). He also chaired the Water Analysis and Research Centre (ALIR) and Integrated Water Resources Management (IWRM) Research Group in UKM, and was the Editor-in-Chief of the Malaysian Journal of Analytical Sciences (MJAS)

Email address: mpauzi1671@gmail.com 


\section{DEVELOPMENT OF A COMPREHENSIVE MODEL FOR EROSION AND SEDIMENT CONTROL TOWARDS GOOD WATER GOVERNANCE: UKM CAMPUS AS A WATERSHED MODEL}
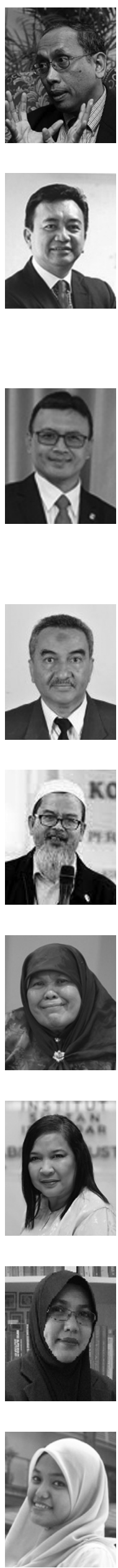

AHMAD FUAD EMBI was a professional engineer with the Department of Irrigation and Drainage (DID) Malaysia beginning in 1976 and retired as its Deputy Director General in 2007. His academic qualifications are BE (Canterbury), DHE (Delft) and MSc (Southampton). At the DID, he pioneered sustainable river management and urban stormwater management. He also led efforts to produce the Malaysian Manual on Urban Stormwater Management (MSMA) in year 2000. Since 2010, he has been an Adjunct Professor with the National University of Malaysia (UKM), where he started an MSc program in erosion and sediment control at the Department of Civil Engineering in 2017.

Email address: fuadembi@gmail.com

MAZLIN BIN MOKHTAR is a Professor of Environmental Chemistry at the National University of Malaysia (UKM). He is currently the Director of the Institute for Environment and Development (LESTARI), UKM. He was previously the Deputy Vice Chancellor of Research and Innovation Affairs at UKM. He was appointed as the Chairman of the Malaysian Environmental Quality Council (EQC) between 2015-2018, the Chairman of Evaluation Committee of Lynas rare earth operations in Malaysia in 2018, and the Deputy Chairman of a special Committee to develop SOP for Bauxite Mining and Exportation in 2019. He is a Fellow of the Malaysian Institute of Chemistry (IKM), Fellow of the Academy of Sciences Malaysia (ASM), Senior Fellow at the Jeffrey Sachs Center on Sustainable Development (JSC), Sunway University; and an Honorary Fellow at the East Coast Environmental Research Institute (ESERI), University of Sultan Zainal Abidin (UniSZA). He has published widely in many forms in various peer reviewed journals and books, and articles, and had supervised, guided, and mentored many next generation leaders, professional managers, and contributors at various levels in Malaysia and Asia. Email address: mazlin@ukm.edu.my

MOHD EKHWAN TORIMAN is a Professor of Environmental Hydrology and River Water Quality Modelling, Research Centre for Social, Development \& Environment at the National University of Malaysia (UKM), and previously was a Deputy Vice Chancellor (Research \& Innovation Affairs) at University Sultan Zainal Abidin (UniSZA) and UKM. He received his first degree (Hons) from UKM, M.Sc from Manchester University, UK and Ph.D from University of Newcastle Upon Tyne, UK. Currently, he has published more than 272 journal papers including 168 that are indexed by ISI and SCOPUS, 78 books and chapters in books and 135 proceedings in national and international conferences. In 2012, he was appointed as a Visiting Scientist and Visiting Professor at Kyoto University, Japan; Mahidol University, Thailand and University of Hassanuddin, Indonesia. He was also a task force member of Academy of Sciences Malaysia (Research \& Development on Water) and currently serves as the Secretary of Natural Resources and Environmental Research Cluster, National Council of Professors (MPN).

Email address: ikhwan@ukm.edu.my

MUHAMMAD BARZANI GASIM is a Principle Research Fellow at the East Coast Environmental Research Institute (ESERI), University of Sultan Zainal Abidin (UniSZA). He was formerly a Professor at the School of Environment and Natural Resource Sciences, Faculty Science and Technology, National University of Malaysia (UKM). He hold a Bachelor of Engineering Geology from the Universitas Pembangunan Nasional, Indonesia (1979); M.Sc. in Structural Geology from the National University of Malaysia (1984); and Ph.D. in Hydrology \&Water Quality from the University of Putra Malaysia (2003). He published numerous research articles in journals, books and chapter in books, proceedings etc. Email address: barzanigasim@unisza.edu.my

SAHIBIN ABD RAHIM is a Professor of Soil Science, Faculty of Science and Natural Resources, University of Malaysia Sabah (UMS). He was formerly a Professor at the School of Earth Sciences and Environment, Faculty Science and Technology, National University of Malaysia (UKM). He received BSc (Hons) in Geology from UKM; PG Dip./ MSc in Agricultural Science from University of Wales, Aberystwyth, UK; and Ph.D. in Agricultural Land Suitability Evaluation (Automated DSS) from University of Wales, Aberystwyth, UK. His research specialisation and interest are mostly in Applied and General Soil Science, Soil Geochemistry, Agricultural land suitability evaluation and Environmental Soil Science.

Email address: sahibin@ums.edu.my

MAIMON ABDULLAH was a Professor of Biology at the School of Environment and Natural Resource Sciences, Faculty Science and Technology, National University of Malaysia (UKM). She received her BSc (Hons) and Dip. Ed. from UKM, MSc from Manchester, and PhD from Bradford. Her specialisation are in Zoology (Invertebrate Biology), Environmental Physiology, Environmental Impact Assessment (EIA), Management and Monitoring.

Email address: maimon.abdullah@gmail.com

ANIZAN ISAHAK was an Associate Professor in the School of Environmental and Natural Resource Sciences, Faculty Science and Technology, National University of Malaysia (UKM), where she has taught since 1982 and received her PhD in Geology in 1993. Her research and publications focus on environmental communication, water resource management, and the ecosystem effects of wet-rice intensification. She taught courses in geological methods and soil science.

Email address: anizanisahak@yahoo.com

NOOR EZLIN AHMAD BASRI is a Professor of Civil and Environmental Engineering, Faculty of Engineering and Built Environment, National University of Malaysia (UKM). She is also the Chair of the Smart and Sustainable Township Research Centre (SUTRA) in UKM. Her research specialisation and interest are related to Solid Waste Engineering, Decision Support System, Engineering Education and Environmental Behaviour. Email address: noorezlin@ukm.edu.my

NORMAIZURA MAIZAN was a Research Assistant at the Institute for Environment and Development (LESTARI), National University of Malaysia (UKM). She holds a Bachelor Degree of Environmental Science and a Master Degree in Environmental Management. She recently joined Malaysian Relief Agency (MRA) as Project Coordinator since 2020. She has various experiences in project management, research and development, Corporate Social Responsibility (CSR), sustainability and event management.

Email address: maizura.maizan@gmail.com 